\title{
Plasma calcium concentrations are decreased at least 9 hours before parturition in multiparous Holstein-Friesian cattle in a herd fed an acidogenic diet during late gestation
}

\author{
Ameer A. Megahed, ${ }^{1}$ Mark W. H. Hiew, ${ }^{2}$ Shymaa A. El Badawy, ${ }^{3}$ and Peter D. Constable ${ }^{1,4}$ \\ Department of Veterinary Clinical Sciences, College of Veterinary Medicine, Purdue University, West Lafayette, IN 47907
}

\begin{abstract}
Calcium homeostatic mechanisms are challenged in periparturient multiparous dairy cattle due to the rapid transport of large amounts of calcium into the mammary gland associated with colostrogenesis, resulting in decreased plasma total calcium concentration ([Ca]). An unresolved issue is the timing of the decrease in plasma $[\mathrm{Ca}]$ relative to the time of parturition, with the consensus view being that plasma [Ca] does not decrease until after parturition. The objective of this study, therefore, was to characterize the change in plasma $[\mathrm{Ca}]$ over time in periparturient dairy cattle. Plasma and mid-stream urine samples were collected daily starting $3 \mathrm{~d}$ before calving from 104 periparturient Holstein-Friesian dairy cows in a herd fed an acidogenic total mixed ration during the late dry period. Mixedmodels ANOVA and linear and multivariable regression analyses were conducted. Plasma $[\mathrm{Ca}]$ decreased in periparturient multiparous cattle $(\mathrm{n}=70)$ but not in primiparous cattle $(\mathrm{n}=34)$. Compared with mean values approximately $72 \mathrm{~h}$ before parturition $([\mathrm{Ca}]=$ $2.32 \mathrm{mmol} / \mathrm{L})$, mean plasma [Ca] in multiparous cattle first decreased at $9 \mathrm{~h}$ before parturition $(2.13 \mathrm{mmol} / \mathrm{L})$ and remained decreased for up to $48 \mathrm{~h}$ after parturition, with the lowest mean value $(1.87 \mathrm{mmol} / \mathrm{L})$ occurring at $28 \mathrm{~h}$ after parturition. Mean 24-h urine Ca excretion was calculated to decrease by 3.5 to $3.8 \mathrm{~g}$ in periparturient multiparous cattle. Regression analysis indicated that plasma $[\mathrm{Ca}]$ in the 12 -h period before and $24-\mathrm{h}$ period after parturition was strongly and negatively

Received June 21, 2017.

Accepted October 6, 2017.

${ }^{1}$ Current address: Department of Veterinary Clinical Medicine, College of Veterinary Medicine, University of Illinois at UrbanaChampaign, IL 61802 .

${ }^{2}$ Current address: Department of Veterinary Clinical Studies, Faculty of Veterinary Medicine, Universiti Putra Malaysia, 43400 Serdang, Selangor, Malaysia.

${ }^{3}$ Current address: Department of Pharmacology, Faculty of Veterinary Medicine, Cairo University, Giza, Egypt.

${ }^{4}$ Corresponding author: constabl@illinois.edu
\end{abstract}

associated with age but was also negatively associated with milk production indices. We conclude that plasma [Ca] was decreased at least $9 \mathrm{~h}$ before parturition in multiparous dairy cattle fed an acidogenic diet in late gestation, and that calcium homeostasis was disrupted for 2 to 3 d around parturition.

Key words: hypocalcemia, colostrogenesis, lactogenesis, urinary calcium excretion

\section{INTRODUCTION}

Most multiparous dairy cows suffer from some degree of hypocalcemia at parturition due to excessive loss of calcium to support fetal growth, colostrogenesis, and milk production (Ramberg et al., 1984; Horst et al., 1994). Acute and severe hypocalcemia occurs when the Ca loss of 1.9 to $2.8 \mathrm{~g} / \mathrm{kg}$ of colostrum (Kume et al., 1998; Bojkovski et al., 2005; Abd El-Fattah et al., 2012 ) and $1.1 \mathrm{~g} / \mathrm{kg}$ of milk (Tsioulpas et al., 2007) dramatically exceeds the Ca present in the exchangeable Ca pool (Ramberg et al., 1970, 1984). The homeostatic response to this $\mathrm{Ca}$ deficit is focused on increasing the rate of bone resorption and gastrointestinal Ca absorption (Martín-Tereso and Verstegen, 2011) and decreasing the rate of bone accretion and urinary $\mathrm{Ca}$ excretion (Ramberg et al., 1970, 1984; Grünberg et al., 2011). These metabolic adaptations are controlled by parathyroid hormone (PTH) and calcitriol (1,25-dihydroxyvitamin $\mathrm{D}_{3}$ ), which are considered the main Ca regulatory hormones in mammals (Ramberg et al., 1970, 1984).

The incidence of subclinical hypocalcemia in the United States varies according to parity; a $25 \%$ incidence has been reported in heifers, $41 \%$ in second-lactation cows, and up to $54 \%$ in third- to fifth-lactation cows (Horst et al., 2003; Reinhardt et al., 2011). Feeding an acidogenic diet for 2 to $3 \mathrm{wk}$ before calving provides a practical and effective approach for preventing subclinical and clinical hypocalcemia in large dairy herds in North America. Feeding an acidogenic diet mitigates the decrease in plasma calcium concentration ([Ca]) in the 24-h period after parturition and decreases the 
incidence of periparturient hypocalcemia from 16.4 to $3.2 \%$ (Charbonneau et al., 2006).

The optimal cutpoint for serum or plasma [Ca] to identify subclinical hypocalcemia and its compromised biological functions is difficult to determine because the capacity to maintain Ca homeostasis is affected by several factors (Thilsing-Hansen et al., 2002; DeGaris and Lean, 2008). The use of cutpoints is unlikely to provide a test with any substantial predictive value in an individual because of the dynamic changes in plasma $[\mathrm{Ca}]$ over the periparturient period in dairy cattle. Nevertheless, identifying cutpoints based on a large study population might yield clinically useful insight into the role of plasma $[\mathrm{Ca}]$ in health disorders and production metrics. For example, a plasma [Ca] $<2.15 \mathrm{mmol} / \mathrm{L}$ might be optimal for identifying subclinical hypocalcemia because this cutpoint identified cows with metritis and reduced numbers and activity of neutrophils (Martinez et al., 2012). The timing of the decrease in plasma [Ca] beyond the cutpoint for subclinical hypocalcemia relative to the time of calving is uncertain, with the consensus view being that plasma $[\mathrm{Ca}]$ does not decrease until after parturition (Goff et al., 2002; Kimura et al., 2006; Reinhardt et al., 2011; Martinez et al., 2012). Calcium homeostasis in periparturient dairy cattle is driven primarily by the balance between calcium intake (a function of the calcium content of the diet and feed intake), the efficiency of $\mathrm{Ca}$ absorption from the gastrointestinal tract, the amount of Ca mobilized from accessible stores, and the amount of calcium lost to the fetus, colostrum, bone accretion, and urinary excretion (Ramberg et al., 1970; Martín-Tereso and Verstegen, 2011). Because Ca is lost to colostrum production and the fetus before parturition, we hypothesized that plasma $[\mathrm{Ca}]$ is decreased before parturition. Accordingly, the primary objective of this study was to characterize the change in plasma [Ca] over time in periparturient primiparous and multiparous Holstein-Friesian cattle fed an acidogenic diet in the late dry period. We also hypothesized that feed intake before parturition, colostral volume (evaluated by ultrasonographic determination of glandular cistern area), calf BW, and degree of skeletal maturity (evaluated by age) were associated with plasma [Ca] in the 24-h period before and after parturition. Secondary objectives were therefore to use multivariable linear regression to identify and prioritize factors associated with plasma $[\mathrm{Ca}]$ in the periparturient period.

\section{MATERIALS AND METHODS}

All methods were evaluated and approved by the Purdue Animal Care and Use Committee (West Lafayette, IN). The study reported here was part of a larger study investigating energy and potassium homeostasis in the periparturient period, and the prediction of parturition and dystocia in Holstein-Friesian cattle. Additional results have been published elsewhere (Megahed et al., 2015, 2017b; Hiew et al., 2016).

\section{Animals, Housing, and Feeding}

A convenience sample of 104 late-gestation nonlactating Holstein-Friesian cattle (34 primiparous and 70 multiparous) from the Purdue University Dairy Research and Education Center were enrolled in the study between May 29, 2012, and March 29, 2013. Two hundred forty animals calved during the course of the study; 136 of these animals were not enrolled in the study due to workload constraints. Enrolled cows were usually moved from the outdoor dry lot to temperaturecontrolled individual box stalls $(3.1 \times 3.1 \mathrm{~m})$ located indoors $4 \mathrm{~d}$ before the estimated parturition date based on breeding records and pregnancy diagnosis at approximately $40 \mathrm{~d}$ after insemination. All animals were deemed healthy based on daily routine physical examinations in the box stalls.

All cattle were fed an acidogenic TMR with DCAD $=-18 \mathrm{mEq} / 100 \mathrm{~g}$ of DM, where DCAD $=\left(\left[\mathrm{Na}^{+}\right]+\right.$ $\left.\left[\mathrm{K}^{+}\right]\right)-\left(\left[\mathrm{Cl}^{-}\right]+\left[\mathrm{S}^{2-}\right]\right)$ based on formulations recommended by the National Research Council for close-up cows (NRC 2001; Table 1). Primiparous and multiparous cattle were fed an acidogenic close-up ration starting 6 and 3 wk before parturition, respectively. The ration was fed once daily between 0800 and $0930 \mathrm{~h}$ and consisted predominantly of grass hay, alfalfa haylage, and corn silage. Water was available ad libitum. Daily amounts of TMR fed and refused (orts) were recorded daily each morning during the study period with wet weight intake $=($ weight of ration fed $)-($ weight of ration refused). Dry matter intake was calculated from wet weight intake using the DM percentage stated in Table 1 . Weekly DM percentages were determined by drying to constant weight and were available for $75 \%$ of the study period, with the $95 \%$ CI for DM percentage being 45 to $56 \%$ for the lactation ration and 43 to $52 \%$ for the close-up ration. Daily Ca intake was calculated from the Ca content stated in Table 1.

The time of calving was recorded to the nearest hour, and the calf and dam separated within a few hours of parturition. Calf birth weight determined as described elsewhere (Hiew et al., 2016). Cows were kept in temperature-controlled individual box stalls for $3 \mathrm{~d}$ after parturition or until they had recovered from any postpartum health disorders before being moved to a freestall barn for lactating cows. Cows were switched to a lactating cow TMR immediately after parturition based on formulations recommended (NRC, 2001) for 
Table 1. Ingredients and chemical composition of the close-up and lactation rations during the study involving 70 multiparous and 34 primiparous Holstein-Friesian cows

\begin{tabular}{|c|c|c|}
\hline Item & Close-up ration & Lactation ration \\
\hline \multicolumn{3}{|l|}{ Ingredient (\% of DM) } \\
\hline Corn silage & 40.5 & 34.6 \\
\hline Orchard grass hay & 14.5 & 3.3 \\
\hline Prefresh grain & 7.2 & - \\
\hline Cottonseed hulls & 6.8 & - \\
\hline Alfalfa silage & 7.0 & 17.0 \\
\hline Soybean meal & 6.1 & 19.1 \\
\hline Biochlor $^{1}$ & 4.9 & - \\
\hline $\begin{array}{l}\text { High-moisture shelled corn } \\
27.6 \%\end{array}$ & 4.3 & 9.4 \\
\hline Corn grain ground & - & 5.0 \\
\hline Soybean hulls pellet & - & 4.3 \\
\hline Double $\mathrm{S}$ molasses $42 \%$ & - & 2.6 \\
\hline LysAAmet Blend $^{2}$ & 1.8 & 1.7 \\
\hline Wheat straw & - & 0.9 \\
\hline Urea & - & 0.2 \\
\hline Omnigen $\mathrm{AF}^{3}$ & 1.5 & 0.1 \\
\hline Megalac $^{1}$ & 0.9 & - \\
\hline $\mathrm{TMV}^{4}$ & 0.9 & - \\
\hline Calcium carbonate & 0.5 & 0.8 \\
\hline Calcium phosphate & 0.5 & - \\
\hline Calcium sulfate & 0.4 & 0.2 \\
\hline Magnesium oxide & 0.1 & 0.2 \\
\hline Magnesium sulfate & 0.1 & - \\
\hline Sodium chloride & 1.0 & - \\
\hline Sodium bicarbonate & - & 0.5 \\
\hline Yeast & 0.3 & — \\
\hline Vitamin E-20,000 & 0.2 & 0.02 \\
\hline Vitamin A 30 & 0.02 & - \\
\hline Niacin $(99 \%)$ & 0.3 & 0.02 \\
\hline Rumensin $90^{5}$ & 0.2 & 0.1 \\
\hline \multicolumn{3}{|l|}{ Chemical analysis } \\
\hline $\mathrm{DM}(\%$ as fed $)$ & 45.53 & 52.04 \\
\hline NDF (\% of DM) & 36.12 & 29.95 \\
\hline $\mathrm{ADF}(\%$ of $\mathrm{DM})$ & 23.65 & 20.83 \\
\hline Forage NDF adjusted (\%) & 26.24 & 24.10 \\
\hline NFC (\%) & 36.00 & 43.25 \\
\hline Sugar $(\%)$ & 2.82 & 4.18 \\
\hline Starch (\%) & 24.76 & 28.02 \\
\hline Forage (\%) & 65.11 & 55.63 \\
\hline $\mathrm{CP}(\%)$ & 15.48 & 16.05 \\
\hline Soluble protein (\%) & 7.10 & 6.61 \\
\hline $\operatorname{RDP}(\%)$ & 7.22 & 10.44 \\
\hline $\mathrm{Ca}(\%)$ & 1.03 & 0.90 \\
\hline $\mathrm{P}(\%)$ & 0.31 & 0.38 \\
\hline $\operatorname{Mg}(\%)$ & 0.43 & 0.36 \\
\hline $\mathrm{K}(\%)$ & 1.20 & 1.30 \\
\hline $\mathrm{Na}(\%)$ & 0.20 & 0.36 \\
\hline $\mathrm{Cl}(\%)$ & 1.14 & 0.52 \\
\hline $\mathrm{S}(\%)$ & 0.39 & 0.22 \\
\hline $\operatorname{Mn}(\mathrm{mg} / \mathrm{d})$ & 89.87 & 81.79 \\
\hline $\mathrm{Cu}(\mathrm{mg} / \mathrm{d})$ & 20.48 & 22.69 \\
\hline $\mathrm{Zn}(\mathrm{mg} / \mathrm{d})$ & 89.75 & 90.35 \\
\hline $\mathrm{I}(\mathrm{mg} / \mathrm{d})$ & 0.52 & 0.56 \\
\hline $\mathrm{Co}(\mathrm{mg} / \mathrm{d})$ & 1.94 & 2.10 \\
\hline $\mathrm{Se}(\mathrm{mg} / \mathrm{d})$ & 0.36 & 0.40 \\
\hline Vitamin A (IU/d) & $8,846.20$ & $7,505.80$ \\
\hline Vitamin $\mathrm{D}_{3}(\mathrm{IU} / \mathrm{d})$ & $1,854.30$ & $1,907.80$ \\
\hline Vitamin E (IU/d) & 207.79 & 43.73 \\
\hline Monensin $^{5}$ (mg) & 31.76 & 11.44 \\
\hline DCAD $(\mathrm{mEq} / 100 \mathrm{~g})$ & -17.50 & +20.40 \\
\hline
\end{tabular}

${ }^{1}$ Arm and Hammer Animal Nutrition (Princeton, NJ).

${ }^{2}$ Perdue AgSolution LLC (Salisbury, MD).

${ }^{3}$ Omnigen AF; Phibro Animal Health Corp. (Ridgefield Park, NJ).

${ }^{4}$ Trace mineral pack; KNS Inc. (Lawrenceburg, KY).

${ }^{5}$ Rumensin 90; Elanco Animal Health (Indianapolis, IN). fresh cows. This ration was based on corn silage, alfalfa haylage, and high-moisture corn (Table 1). After parturition, cows were milked twice daily between 0515 and $0830 \mathrm{~h}$ and between 1600 and $1900 \mathrm{~h}$, in a milking parlor. Daily milk production was recorded using the dairy's automatic recording software (PCDART, Dairy Records Management Systems, Raleigh, NC).

\section{Experimental Study}

Urine and blood sampling and ultrasonographic measurement of gland cistern area were performed daily between 0800 and $1000 \mathrm{~h}$ with the animal gently restrained in a headlock. Mid-stream urine samples were collected by perineal stimulation into a $20-\mathrm{mL}$ plastic collection cup on $\mathrm{d}-3,-2,-1,0,1,2$, and 3 relative to calving (d 0 ). The vials were completely filled with urine and immediately closed to minimize exposure to air. Urine samples were then placed in a water bath at $38^{\circ} \mathrm{C}$ and urine $\mathrm{pH}$ measured within 15 min of collection using a pH meter (Orion 520A, Thermo Electron Corp., Beverly, MA). Urine samples were stored at $-20^{\circ} \mathrm{C}$ for further analysis.

Blood samples were obtained daily at approximately $0900 \mathrm{~h}$ from the coccygeal vein or artery on $\mathrm{d}-3,-2$, $-1,0,1,2$, and 3 relative to calving using 20-gauge Vacutainer needles, Vacutainer holders, and 10-mL lithium heparin blood collection tubes (BD Diagnostics, Franklin Lakes, NJ). The proposed puncture site at the ventrum of the tail was cleared of debris and feces by swabbing the site with gauze containing $70 \%$ isopropyl alcohol. Heparinized blood samples were centrifuged for $5 \mathrm{~min}$ at $1,300 \times g$ within $30 \mathrm{~min}$ of collection. Plasma total protein concentration in the resulting plasma was measured in triplicate on the same small volume of plasma using a hand-held analog refractometer (Master-Sur/No, Atago Co Ltd., Bellevue, WA). The remainder of the plasma sample was transferred into polypropylene vials within $1 \mathrm{~h}$ of centrifugation and stored at $-20^{\circ} \mathrm{C}$ for further analysis.

The thoracic circumference (heart girth) in a vertical plane immediately caudal to the scapula was measured once before parturition with the animal standing on level ground and its weight evenly distributed. Body weight was calculated from the thoracic circumference using a linear equation developed from Holstein-Friesian heifers aged 1 to $821 \mathrm{~d}$ (Heinrichs et al., 1992).

Ultrasonographic measurement of the gland cistern area was performed on $\mathrm{d}-4,-3,-2$, and -1 relative to parturition (d 0) as described (Ayadi et al., 2003). The cow was placed in a headlock in a normal standing position and one front gland was selected for imaging based on the ease of recording. Care was taken to minimize external stimulation of the teat and thus oxytocin 
release by the cow and potential increase in cisternal milk due to mixing of alveolar and cistern milk (Caja et al., 2004), but an oxytocin receptor blocker was not administered before ultrasonographic examination. Release of oxytocin during ultrasonography was thought to be minimal because we did not observe streaming of echogenic fluid into the gland cistern during imaging and because ultrasonography was performed in calving pens located approximately $100 \mathrm{~m}$ from the dairy parlor. Oxytocin release is minimized when cows are milked in unfamiliar surroundings (Bruckmaier et al., 1994).

Optimal ultrasonographic image quality was obtained by cleaning the skin overlying the quarter with a brush to remove gross dirt and debris. Coupling gel was then applied to the ventral and caudal aspects of the gland, and a 5-MHz wide band linear probe (Exago, Universal Solutions Inc., Bedford Hills, NY) was held horizontally and placed caudal to the base of the teat. The ultrasonographic beam was directed vertically at right angles to the long axis of the body with the center of the linear probe aligned with the center of the teat. The depth setting of the ultrasound unit was set to 8 , 10,12 , or $15 \mathrm{~cm}$ depending on the deepest portion of the gland cistern that could be visualized. The ultrasonographic image with the largest contiguously viewable gland cistern area was stored in JPEG (.jpg) format $(640 \times 480$ pixels $)$ for analysis offline.

\section{Urine and Plasma Biochemical Analysis}

Stored urine samples were thawed at room temperature and vortexed for $10 \mathrm{~s}$ immediately before biochemical analysis. Urine concentrations of Ca (cresolphthalein), magnesium ( $\mathrm{Mg}$, xylidyl blue binding), inorganic phosphate (Pi, ammonium molybdate), and creatinine (picric acid) were determined spectrophotometrically (AU680, Beckman Coulter Inc., Brea, CA) at the Veterinary Diagnostic Laboratory, College of Veterinary Medicine (University of Illinois, Urbana-Champaign) using appropriate dilutions.

Urine Ca excretion $(\mathrm{g} / \mathrm{d})$ for each 24 -h period was calculated from d 3 prepartum to d 3 postpartum using the measured urine Ca concentration ([urine Ca], expressed in $\mathrm{mg} / \mathrm{dL})$, measured urine creatinine concentration ([urine creatinine], expressed in $\mathrm{mg} / \mathrm{dL}$ ), and the calculated BW $(\mathrm{kg})$, assuming a constant urine creatinine excretion of $0.029 \mathrm{~g} / \mathrm{kg}$ of BW (Valadares et al., 1999; Martín-Tereso and Verstegen, 2011), such that urine $\mathrm{Ca}$ excretion $=([$ urine $\mathrm{Ca}] /[$ urine creatinine $]) \times$ $0.029 \times \mathrm{BW}$.

Mean prepartum urine $\mathrm{Ca}$ excretion was calculated using a different method from the ration DCAD using the following quadratic equation developed from experimental data involving multiparous cows (Roche et al., 2003a): urine Ca excretion $=1.547 \times(0.001 \times$ $\left.\mathrm{DCAD}^{2}-0.1075 \times \mathrm{DCAD}+2.794\right)$. This equation assumes a constant daily creatinine excretion of $17.5 \mathrm{~g}$ for a $600-\mathrm{kg}$ cow (equivalent to that predicted by the equation above; Valadares et al., 1999), and produces an estimate for daily urine Ca excretion that is strongly correlated $(\mathrm{r}=0.87)$ with the measured value (MartínTereso and Verstegen, 2011). Mean postpartum urine Ca excretion was calculated using a similar approach from the ration DCAD using the following linear equation developed from experimental data involving multiparous cows (Roche et al., 2003b): urine Ca excretion $=1.547 \times(-0.0027 \times \mathrm{DCAD}+0.622)$.

Plasma concentrations of total Ca (cresolphthalein), Mg (xylidyl blue binding), Pi (ammonium molybdate), and creatinine (picric acid) were determined spectrophotometrically (AU680, Beckman Coulter Inc., Brea, $\mathrm{CA})$ at the same laboratory as the urine samples.

\section{Ultrasonographic Measurement of Gland Cistern Area}

Gland cistern area was defined as the area of the visible anechogenic portion of the image, which is easily discriminated from the echogenic glandular parenchyma (Ayadi et al., 2003). Gland cistern area was measured using the ImageJ software program (http:// rsbweb.nih.gov/ij/download.html) by hand tracing the outline of the contiguously viewable anechogenic portion after calibrating image depth (Ayadi et al., 2003). The mean of 3 area measurements of each figure was used for statistical analysis. The percentage change in gland cistern area over the previous $24 \mathrm{~h}$ was calculated on $\mathrm{d}-3,-2$, and -1 from the measured gland cistern area on day $i$, such that percentage change $=\left(\right.$ area $_{i+1}$ - area $\left._{i}\right) \times 100 /$ area $_{i}$.

\section{Statistical Analysis}

Data were expressed as mean \pm standard deviations or median and range, and $P<0.05$ was considered significant. Data were categorized into 6-, 12-, or 24 -h intervals relative to the time of calving for statistical analysis of changes over time. Mixed-models ANOVA was used to detect the main effects of parity (2 levels), time, and the interaction between parity and time. Time was included in the model as a repeated variable. Cow nested within parity was included in the model as a random effect whenever the between-subjects variation was determined to be significant (Littell et al., 1998; Liu et al., 2007). An autoregressive covariance structure was used based on the lowest value for Akaike's information criterion. Data for some variables needed 
to be log-transformed (DMI, urine Ca excretion) or ranked (plasma $[\mathrm{Mg}]$, urine $\mathrm{pH}$ ) to achieve homogeneity of variance and an approximately normal distribution for residuals. Whenever the $F$-test was significant, Bonferroni-adjusted $P$-values were used to assess differences between primiparous and multiparous cattle at a specific time, and between $\mathrm{d}-3$ and subsequent days within a parity group.

Univariable linear regression was used to evaluate the individual association between plasma [Ca] and the following continuous variables: age, calf birth weight, gland cistern area, DMI, milk production on d 28 of lactation, cumulative 28-d milk production, 305-d mature-equivalent milk production, and total milk production for the lactation. The 28-d time interval was selected for analysis because postparturient oral Ca supplementation increased milk yield in the first 30 DIM in multiparous cows of greater production potential (Martinez et al., 2016b). Forward stepwise linear regression was conducted using the same variables with $P=0.05$ to enter and exit the model. Separate analyses were conducted for the 12 -h period before parturition

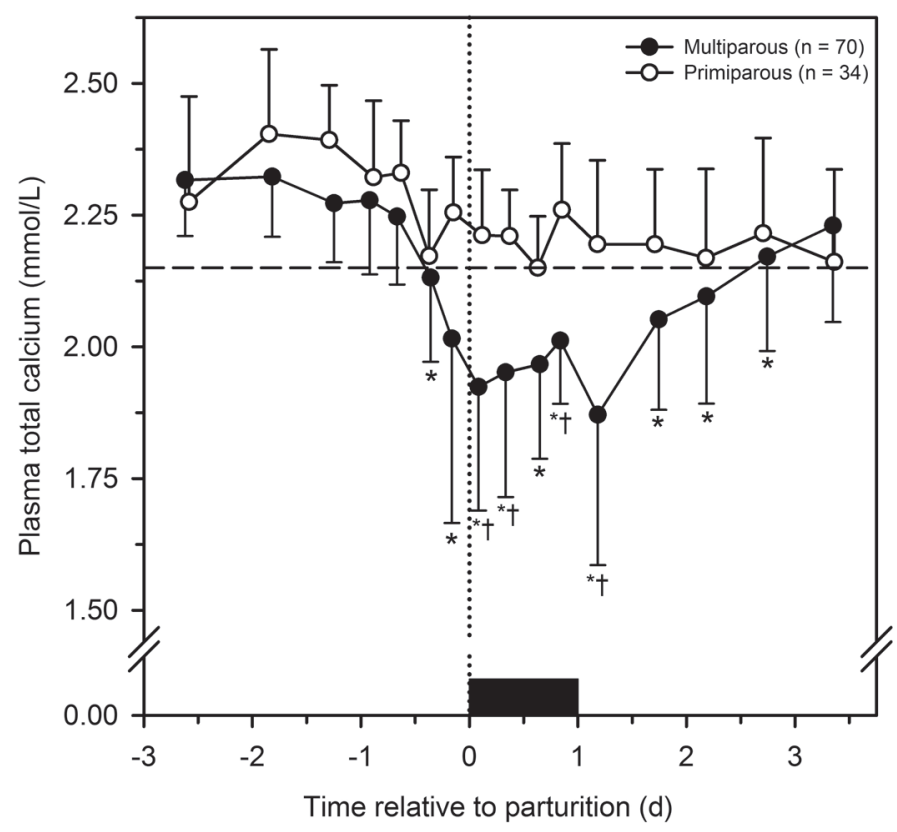

Figure 1. Plasma total calcium concentrations for multiparous (filled circles, $\mathrm{n}=70$ ) and primiparous (open circles, $\mathrm{n}=34$ ) HolsteinFriesian cattle at selected intervals from $3 \mathrm{~d}$ prepartum to $3 \mathrm{~d}$ postpartum. Time is expressed as the mean time that data were recorded for each 6-, 12-, or 24-h interval. The black rectangle is the 24 -h period during which all cows calved, and the dotted horizontal line is the lower limit of the reference range for healthy cattle $(2.15 \mathrm{mmol} / \mathrm{L})$. The dashed vertical line indicates parturition. Data are presented as mean \pm SD. ${ }^{*} P<0.0033$ (Bonferroni adjusted) compared with the mean value obtained between $\mathrm{d}-3$ and $-2 ; \dagger P<0.0031$ (Bonferroni adjusted) compared with the value for primiparous cattle at the same time. and the 24-h period after parturition; the latter analysis did not consider calf birth weight. All analyses were performed with SAS software (PROC UNIVARIATE, PROC MIXED, PROC REG; SAS 9.4, SAS Inst. Inc., Cary, NC).

\section{RESULTS}

Four multiparous cows produced twins. Clinical signs of periparturient hypocalcemia were identified in 7 cows (6.7\% of the study population and $8.6 \%$ of multiparous cattle) aged $7,7,6,6,4,4$, and 2 yr in the first 24 $\mathrm{h}$ after parturition. These cows were treated with IV calcium gluconate before they could be examined in the first $24 \mathrm{~h}$ after parturition; laboratory and milk production measurements from these cows were not included in the statistical analysis for d 0 onward. Four other cows $(8,7,6$, and $6 \mathrm{yr})$ were treated with $50 \mathrm{~g}$ of calcium in a commercially available oral bolus (Bovikalc, Boehringer Ingelheim Vetmedica Inc., St. Joseph, MO) after the cows were examined in the first $24 \mathrm{~h}$ after parturition. The 4 cows were administered oral calcium because they had exhibited clinical signs of periparturient hypocalcemia in the previous lactation. Laboratory and milk production measurements from these cows were not included in the statistical analysis from d 1 onward. Consequently, statistical analysis of plasma [Ca] used data from all 104 cattle in the 24-h period before parturition, 97 cattle in the 24 -h period after parturition, and 93 cattle from 24 to $72 \mathrm{~h}$ after parturition.

\section{Plasma Biochemical Analysis}

Mean plasma [Ca] decreased in periparturient multiparous cattle but not in primiparous cattle (Figure 1). Compared with mean values approximately $72 \mathrm{~h}$ before parturition $([\mathrm{Ca}]=2.32 \mathrm{mmol} / \mathrm{L})$, plasma $[\mathrm{Ca}]$ in multiparous cattle was first decreased at $9 \mathrm{~h}$ before parturition $(2.13 \mathrm{mmol} / \mathrm{L})$, was lower $(1.92 \mathrm{mmol} / \mathrm{L})$ at $2 \mathrm{~h}$ after parturition, increased to $1.97 \mathrm{mmol} / \mathrm{L}$ at $16 \mathrm{~h}$ and then decreased to $1.87 \mathrm{mmol} / \mathrm{L}$ at $28 \mathrm{~h}$ after parturition, after which time plasma $[\mathrm{Ca}]$ gradually increased to the reference range approximately $72 \mathrm{~h}$ after parturition.

Mean plasma $[\mathrm{Pi}]$ in primiparous and multiparous cattle was $1.84 \mathrm{mmol} / \mathrm{L}$ at approximately $72 \mathrm{~h}$ before parturition (Figure 2). Mean plasma [Pi] decreased in periparturient multiparous cattle but not in primiparous cattle. Mean plasma $[\mathrm{Pi}]$ in multiparous cattle appeared to decrease in 2 waves: the first decrease was at $2 \mathrm{~h}$ after parturition $(1.27 \mathrm{mmol} / \mathrm{L})$, and the second decrease was at $26 \mathrm{~h}$ after parturition $(1.22 \mathrm{mmol} / \mathrm{L})$. 
Mean plasma $[\mathrm{Mg}]$ in primiparous and multiparous cattle was maintained within the reference range for healthy cattle $(0.62$ to $1.11 \mathrm{mmol} / \mathrm{L})$ during the whole study (Figure 3). Mean plasma $[\mathrm{Mg}]$ in primiparous and multiparous cattle was $0.88 \mathrm{mmol} / \mathrm{L}$ at approximately $72 \mathrm{~h}$ before parturition. Mean plasma $[\mathrm{Mg}]$ in multiparous cattle was decreased to $0.81 \mathrm{mmol} / \mathrm{L}$ at 24 $\mathrm{h}$ before parturition and then increased to reach a peak $(0.97 \mathrm{mmol} / \mathrm{L})$ at $18 \mathrm{~h}$ after parturition, after which time mean plasma $[\mathrm{Mg}]$ gradually decreased to 0.79 mmol/L approximately $72 \mathrm{~h}$ after parturition.

\section{Urine Biochemical Analysis}

Mean urine $\mathrm{pH}$ in primiparous and multiparous cattle at approximately $72 \mathrm{~h}$ before parturition was 6.4 and 6.5, respectively (Figure 4). Compared with these mean values, urine $\mathrm{pH}$ in primiparous and multiparous cattle was first increased at approximately $25 \mathrm{~h}$ after parturition (7.5 and 7.7, respectively), was higher (8.0) at approximately $32 \mathrm{~h}$ after parturition, and then plateaued approximately $72 \mathrm{~h}$ after calving.

Urine [Ca], urine [creatinine], urine [Ca]:[creatinine], and calculated daily $\mathrm{Ca}$ excretion at 12 - to 24 -h in-

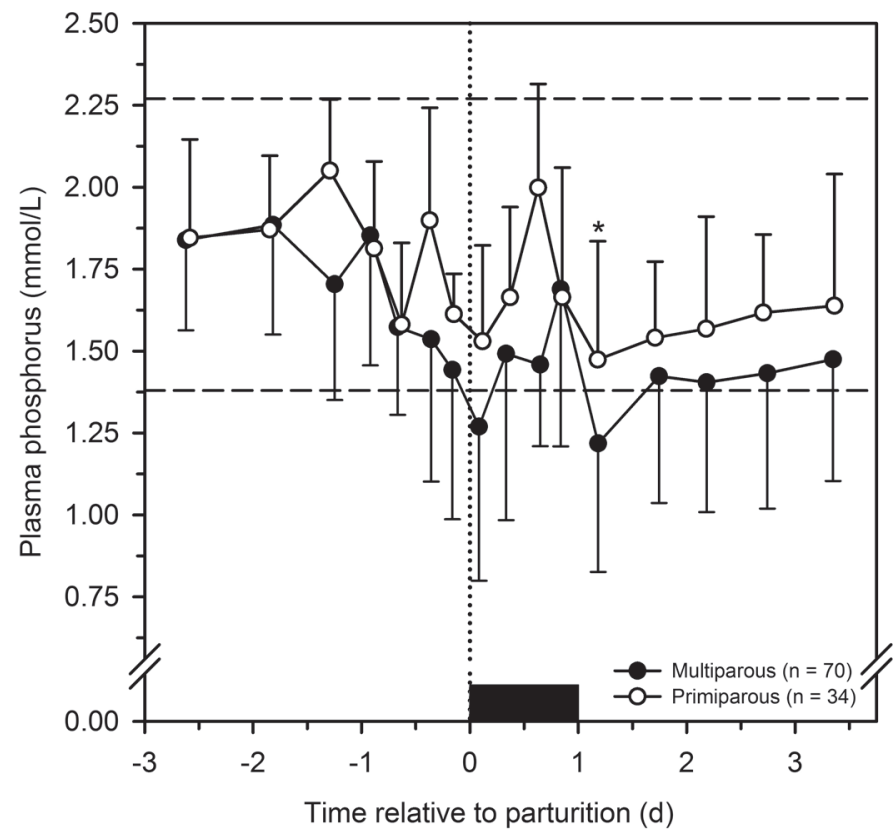

Figure 2. Plasma phosphorus concentrations for multiparous (filled circles, $n=70$ ) and primiparous (open circles, $n=34$ ) HolsteinFriesian cattle at selected intervals from $3 \mathrm{~d}$ prepartum to $3 \mathrm{~d}$ postpartum. Time is expressed as the mean time that data were recorded for each 6-, 12-, or 24-h interval. The black rectangle is the 24 -h period during which all cows calved, and the dashed horizontal lines are the upper and lower limits of the reference range for healthy cattle. The dotted vertical line indicates parturition. Data are presented as mean $\pm \mathrm{SD} .{ }^{*} P<0.0033$ (Bonferroni adjusted) compared with the mean value obtained between $\mathrm{d}-3$ and -2 .

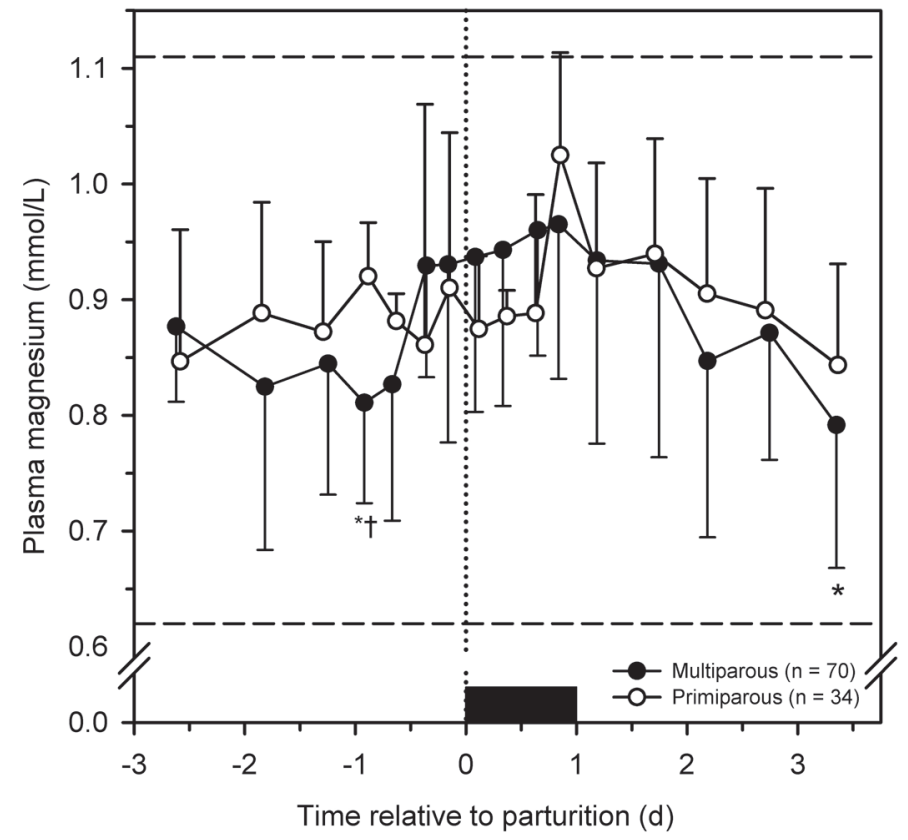

Figure 3. Plasma magnesium concentrations for multiparous (filled circles, $\mathrm{n}=70$ ) and primiparous (open circles, $\mathrm{n}=34$ ) HolsteinFriesian cattle at selected intervals from $3 \mathrm{~d}$ prepartum to $3 \mathrm{~d}$ postpartum. Time is expressed as the mean time that data were recorded for each interval. The black rectangle is the 24 -h period during which all cows calved, and the dashed horizontal lines are the upper and lower limits of the reference range for healthy cattle. The dotted vertical line indicates parturition. Data are presented as mean $\pm \mathrm{SD} .{ }^{*} P<$ 0.0033 (Bonferroni adjusted) compared with the mean value obtained between $\mathrm{d}-3$ and $-2 ; \dagger P<0.0031$ (Bonferroni adjusted) compared with the value for primiparous cattle at the same time.

tervals are presented in Table 2. The mean amount of $\mathrm{Ca}$ excreted in urine in primiparous and multiparous cattle at approximately $72 \mathrm{~h}$ before calving was calculated as 9.2 and $6.9 \mathrm{~g} / \mathrm{d}$, respectively, using the equation developed by Valadares et al. (1999; Figure 5). In primiparous cattle, mean urine Ca excretion decreased to $4.7 \mathrm{~g} / \mathrm{d}$ at approximately $48 \mathrm{~h}$ before parturition and continued to decrease gradually, reaching a nadir $(0.1 \mathrm{~g} / \mathrm{d})$ at approximately $30 \mathrm{~h}$ after parturition. In multiparous cattle, urine $\mathrm{Ca}$ excretion decreased from a calculated mean of $5.5 \mathrm{~g} / \mathrm{d}$ at approximately $24 \mathrm{~h}$ before parturition to $1.7 \mathrm{~g} / \mathrm{d}$ at parturition (equivalent to an effective reabsorption of $3.8 \mathrm{~g}$ of Ca over the $24-\mathrm{h}$ period). Similarly, urine $\mathrm{Ca}$ excretion decreased from a calculated mean of $6.9 \mathrm{~g} / \mathrm{d}$ at approximately $12 \mathrm{~h}$ before parturition to $3.4 \mathrm{~g} / \mathrm{d}$ at approximately $12 \mathrm{~h}$ after parturition (equivalent to an effective reabsorption of $3.5 \mathrm{~g}$ of $\mathrm{Ca}$ over the $24 \mathrm{~h}$ period). In other words, 3.5 to $3.8 \mathrm{~g}$ of Ca was reabsorbed from urine over $24 \mathrm{~h}$ in periparturient multiparous cattle.

The estimated daily mean urine Ca excretion was 7.7 $\mathrm{g} / \mathrm{d}$ before parturition and $1.0 \mathrm{~g} / \mathrm{d}$ after parturition, 


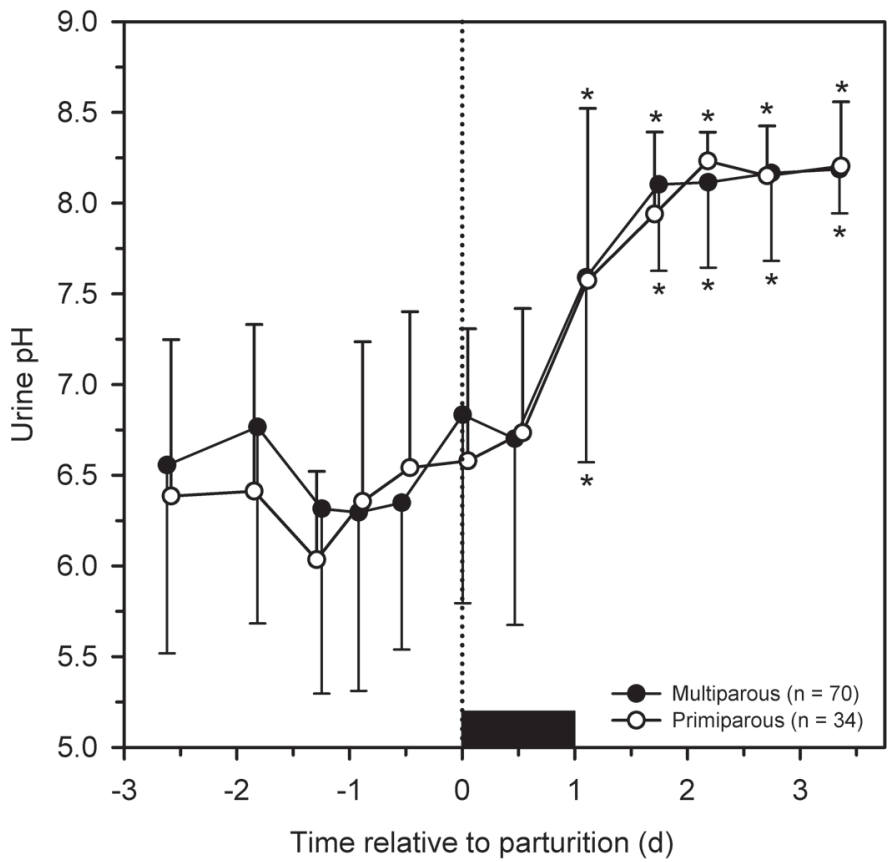

Figure 4. Preprandial free-catch urine $\mathrm{pH}$ for multiparous (filled circles, $\mathrm{n}=70$ ) and primiparous (open circles, $\mathrm{n}=34$ ) HolsteinFriesian cattle at selected intervals from $3 \mathrm{~d}$ prepartum to $3 \mathrm{~d}$ postpartum. Time is expressed as the mean time that data were recorded for each interval. The black rectangle is the 24 -h period during which all cows calved. The dotted line indicates parturition. Data are presented as mean $\pm \mathrm{SD} .{ }^{*} P<0.0033$ (Bonferroni adjusted) compared with the mean value obtained between $\mathrm{d}-3$ and -2 .

using a quadratic equation (Roche et al., 2003a) and linear equation (Roche et al., 2003b), respectively. The estimated mean daily $\mathrm{Ca}$ excretion values were within $1 \mathrm{SD}$ of the mean prepartum and postpartum values for multiparous cattle calculated from urine $[\mathrm{Ca}]$ and [creatinine] (Figure 5).

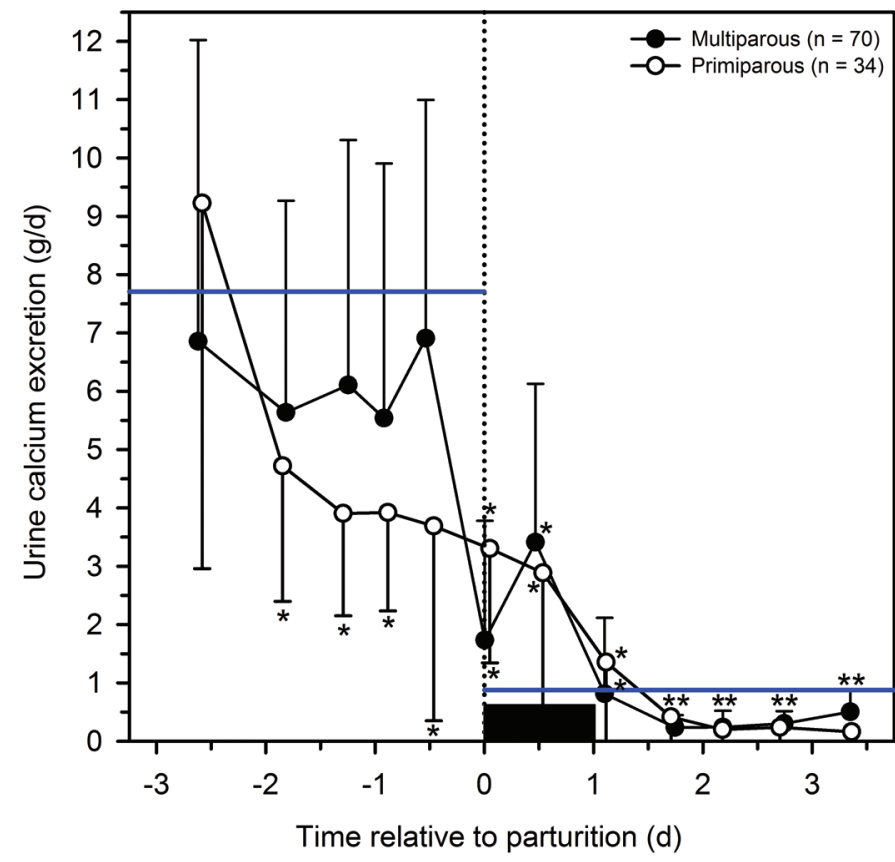

Figure 5. Calculated urine calcium excretion for multiparous (filled circles, $\mathrm{n}=70$ ) and primiparous (open circles, $\mathrm{n}=34$ ) HolsteinFriesian cattle at selected intervals from $3 \mathrm{~d}$ prepartum to $3 \mathrm{~d}$ postpartum. Time is expressed as the mean time that data were recorded for each interval. The black rectangle is the 24 -h period during which all cows calved. The dotted line indicates parturition. Data are presented as mean $\pm \mathrm{SD} .{ }^{*} P<0.005$ (Bonferroni adjusted) compared with the mean value obtained between $\mathrm{d}-3$ and -2 . The solid horizontal lines represent the mean daily $\mathrm{Ca}$ excretion calculated from the ration DCAD value using a quadratic equation (prepartum, Roche et al., 2003a) or a linear equation (postpartum, Roche et al., 2003b). Color version available online.

\section{DMI and Calcium Intake}

We detected marked cow-to-cow variability in DMI. Mean DMI in multiparous and primiparous cattle at d 3

Table 2. Urine Ca concentration ([Ca]), creatinine concentration ([Creatinine]), urine [Ca] to [Creatinine] ratio, and calculated daily urine Ca excretion for primiparous $(\mathrm{n}=34)$ and multiparous $(\mathrm{n}=70)$ Holstein-Friesian cattle at selected intervals from $3 \mathrm{~d}$ prepartum to $3 \mathrm{~d}$ postpartum ${ }^{1}$

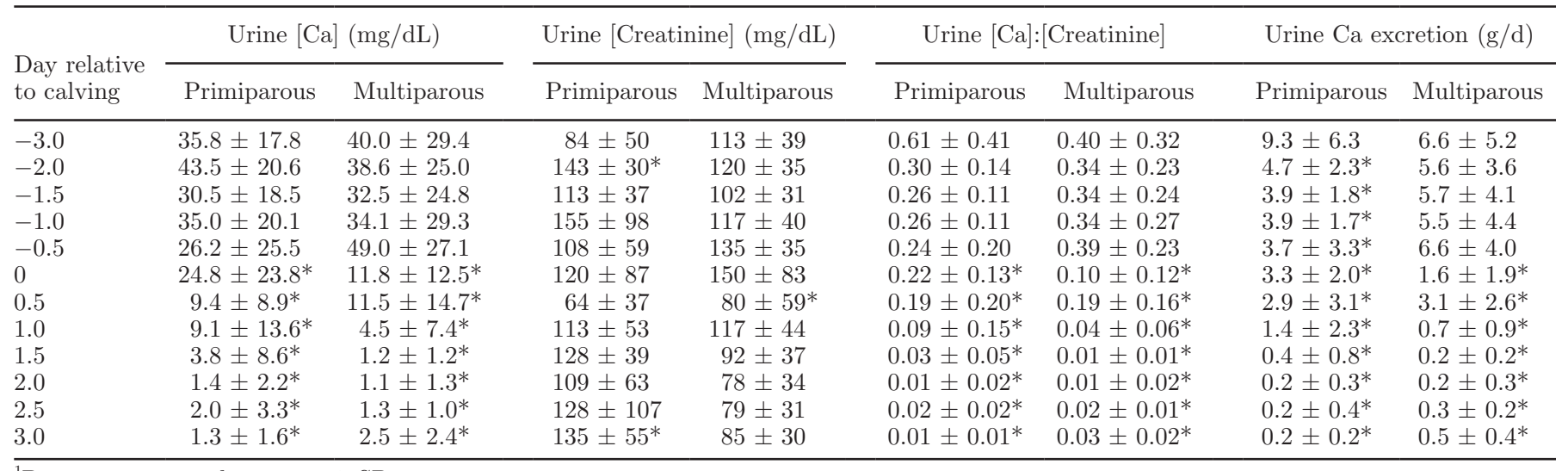

${ }^{1}$ Data are presented as mean \pm SD.

$* P<0.005$ (Bonferroni adjusted) compared with the mean value obtained on $\mathrm{d}-3$. 
prepartum was $10.7 \pm 2.9$ and $7.9 \pm 1.5 \mathrm{~kg}$, respectively (Figure 6). Compared with these mean values, DMI decreased to $9.8 \pm 4.0 \mathrm{~kg}$ on the day before parturition in multiparous cattle and increased in both multiparous and primiparous cattle on the day after parturition.

There was also marked cow-to-cow variability in calculated daily $\mathrm{Ca}$ intake. Mean Ca intake in multiparous and primiparous cattle at $\mathrm{d} 3$ prepartum was $110 \pm 30$ and $81 \pm 15 \mathrm{~g}$, respectively. On the day before calving, mean Ca intake in multiparous and primiparous cattle was $101 \pm 41$ and $70 \pm 27 \mathrm{~g}$, respectively.

\section{Ultrasonographic Measurement of Gland Cistern Area}

Ultrasonographic images were available from 45 animals (13 primiparous, 32 multiparous) on all $4 \mathrm{~d}$ before parturition, and this data set was used to determine changes in glandular cistern area over time. Glandular parenchyma and gland cistern were evident in all scans, with variable degrees of udder edema visible in the subcutaneous space, particularly in primiparous cattle. The front gland cistern area was largest when measured by placing the transducer caudal to the teat. The median coefficient of variation for measuring gland cistern area caudal to the teat from 12 randomly selected animals was $2.6 \%$ (range, $0.4-5.5 \%$ ). This was similar to the coefficient of variation for gland cistern area measured by placing the transducer cranial $(2.6 \%)$, lateral $(2.0 \%)$, or medial $(3.0 \%)$ to the teat.

There was marked cow-to-cow variability in gland cistern area, and the main effect for parity $(P=0.19)$ and the interaction of parity and time $(P=0.87)$ on gland cistern area were not significant (Figure 7). There was a significant effect of time on gland cistern area $(P<0.0001)$, which increased by a mean of 11,11 , and $23 \%$, and by 9,7 , and $23 \%$ for the 3 consecutive days before parturition in primiparous and multiparous cattle, respectively.

Cistern area measured ultrasonographically in the 24-h period before parturition explained little of the variance in first milking weight after parturition $(\mathrm{n}=$ $74 ; \mathrm{R}^{2}=0.07 ; P=0.028$; Figure $8 \mathrm{~A}$ ), milk production on d $28\left(\mathrm{n}=82 ; \mathrm{R}^{2}=0.06 ; P=0.029 ;\right.$ Figure $\left.8 \mathrm{~B}\right)$; cumulative $28-\mathrm{d}$ milk production $\left(\mathrm{n}=82 ; \mathrm{R}^{2}=0.06 ; P\right.$ $=0.031)$, or total milk production for the lactation $(\mathrm{n}$ $\left.=81 ; \mathrm{R}^{2}=0.05 ; P=0.045\right)$.

\section{Factors Associated with Plasma [Ca] Immediately Before Parturition}

Forty of the 104 animals were examined within the 12 -h period before parturition. Univariable linear regression of the 12-h period before parturition indicated

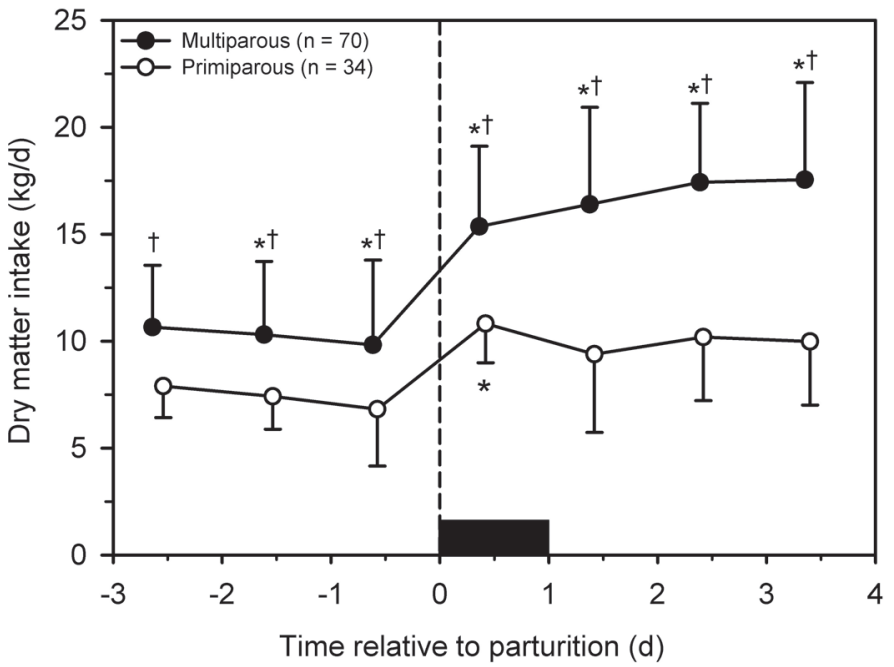

Figure 6. Dry matter intake for multiparous (filled circles, $\mathrm{n}=70$ ) and primiparous (open circles, $\mathrm{n}=34$ ) Holstein-Friesian cattle from 3 $\mathrm{d}$ prepartum to $3 \mathrm{~d}$ postpartum. Time is expressed as the mean time that data were recorded for each interval. The black rectangle is the 24 -h period during which all cows calved. The vertical dashed line indicates parturition. Data are presented as mean $\pm \mathrm{SD}$. ${ }^{*} P<0.0085$ (Bonferroni adjusted) compared with the mean value obtained during $\mathrm{d}-3 ; \dagger P<0.0071$ (Bonferroni adjusted) compared with the value for multiparous cattle at the same time.

that plasma $[\mathrm{Ca}]$ was most strongly associated with age $\left(\mathrm{n}=40 ; \mathrm{R}^{2}=0.32 ; P=0.0002 ;\right.$ Figure $\left.9 \mathrm{~A}\right)$. Plasma $[\mathrm{Ca}]$ was also negatively associated with cistern area (n $=33 ; \mathrm{R}^{2}=0.19 ; P=0.011$; Figure 9B). The following variables were not associated with plasma $[\mathrm{Ca}]$ in the

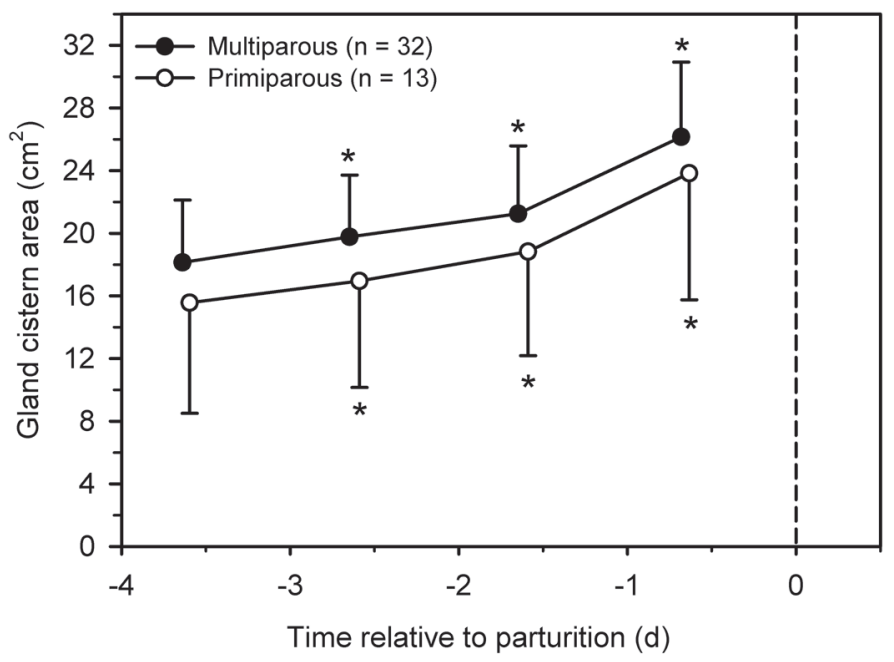

Figure 7. Gland cistern area for multiparous (filled circles, $\mathrm{n}=$ 32 ) and primiparous (open circles, $n=13$ ) Holstein-Friesian cattle measured ultrasonographically caudal to the teat in one forequarter each day for the last $4 \mathrm{~d}$ prepartum. Time is expressed as the mean time that data were recorded for each interval. The vertical dashed line indicates parturition. Data are presented as mean $\pm \mathrm{SD} .{ }^{*} P<$ 0.005 (Bonferroni adjusted) compared with the mean value obtained during $\mathrm{d}-4$. 


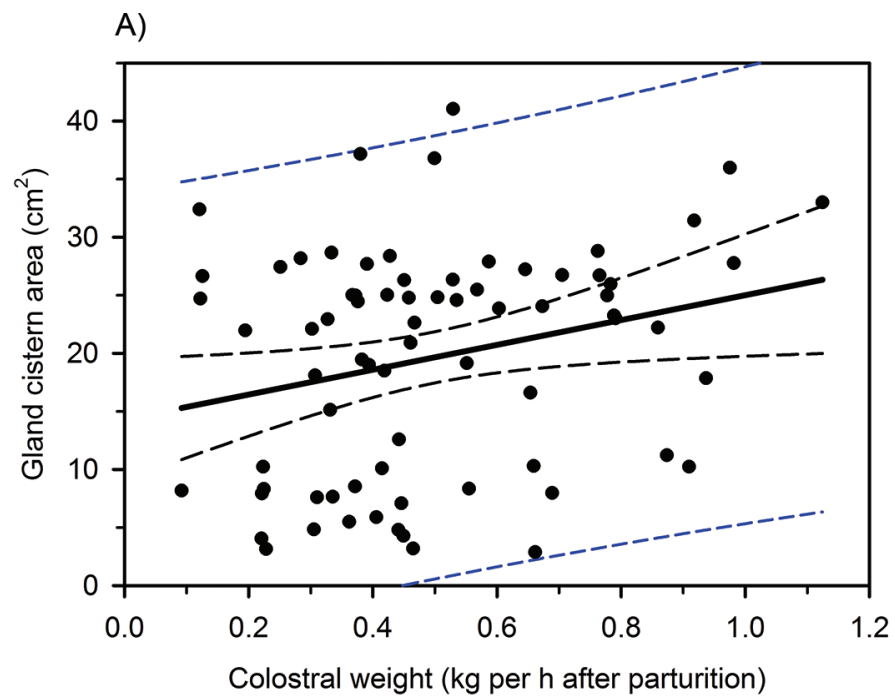

B)

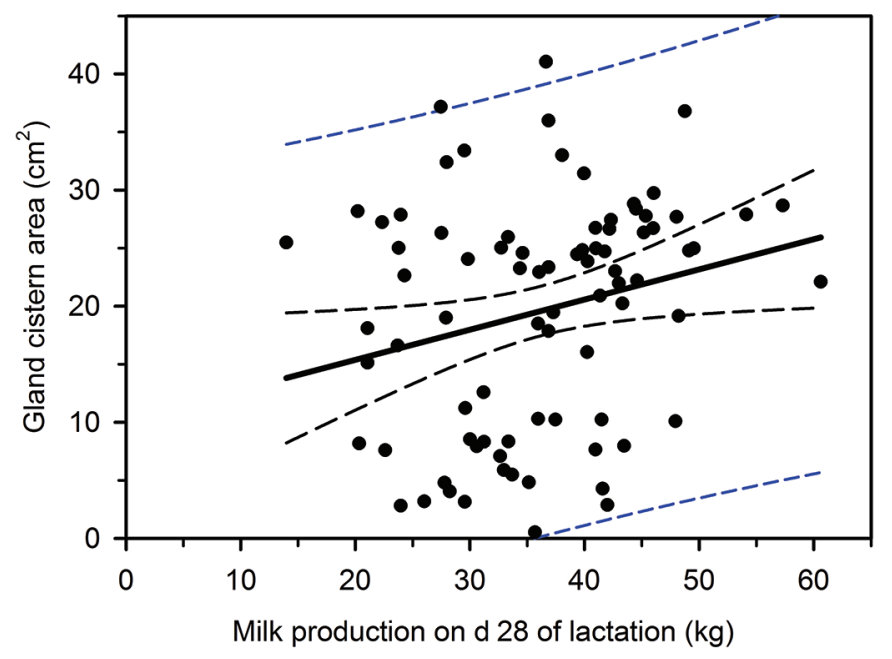

Figure 8. (A) Positive linear relationship between gland cistern area measured in the last $24 \mathrm{~h}$ before parturition and first milking colostral weight collected after parturition in 74 Holstein-Friesian cattle. Gland cistern area was measured ultrasonographically in one forequarter. First milking colostral weight was indexed to time since parturition. The solid line is the regression line $[$ area $=14.3+10.7 \times$ (weight per h)], the medium dashed line is the $95 \%$ CI for the regression line, and the short dashed line is the $9 \%$ CI for prediction. (B) Positive linear relationship between gland cistern area measured in the last $24 \mathrm{~h}$ before parturition and milk production on d 28 of lactation in 74 Holstein-Friesian cattle; regression equation: area $=10.2+0.26$ $\times$ (production on d 28). Color version available online.

12-h period before parturition: DMI $(\mathrm{n}=38, P=0.12)$, calf birth weight $(\mathrm{n}=39, P=0.38)$, and change in cistern area $(\mathrm{n}=23, P=0.42)$.

Stepwise multivariable linear regression identified age as the only significant factor associated with plasma [Ca] in the 12-h period before parturition, although DMI $(P=0.061)$ was close to being significant as the second variable to enter the regression model.

\section{Factors Associated with Plasma [Ca] Immediately After Parturition}

Plasma [Ca] values were available for 97 untreated animals in the 24-h period after parturition. Univariable linear regression indicated that plasma [Ca] was most strongly associated with age $\left(\mathrm{n}=97 ; \mathrm{R}^{2}=0.48\right.$; $P<0.0001$; Figure 9C). Plasma [Ca] in the 24 -h period after parturition explained 28 to $33 \%$ of the variance in milk production indices, being negatively associated with milk production on d 28 of lactation $\left(\mathrm{n}=97 ; \mathrm{R}^{2}\right.$ $=0.33 ; P<0.0001 ;$ Figure 9D), cumulative 28-d milk production $\left(\mathrm{n}=96 ; \mathrm{R}^{2}=0.29 ; P<0.0001\right)$, and total milk production $\left(\mathrm{n}=95 ; \mathrm{R}^{2}=0.28 ; P=0.047\right)$.

Calves were separated from their dams as soon as possible after birth (almost all within $1 \mathrm{~h}$ ) and calves were not observed to suckle the dam. The time to first milking was shorter $(P=0.009)$ for multiparous cattle $(5.2 \pm 1.8 \mathrm{~h}, \mathrm{n}=59)$ than for primiparous cattle $(6.6 \pm$ $2.5 \mathrm{~h}, \mathrm{n}=30)$. Median values for first milking colostral volume were similar $(P=0.63)$ for multiparous cattle $(2.5 \mathrm{~L}$; range, 0.3 to $9.8 \mathrm{~L})$ and primiparous cattle $(2.5$ $\mathrm{L}$; range, 0.8 to $6.7 \mathrm{~L}$ ). Plasma [Ca] in the 24 -h period after parturition was not linearly associated with the following factors: DMI $(\mathrm{n}=95, P=0.053), 305-\mathrm{d}$ milk production $(\mathrm{n}=94, P=0.17)$, milk production at first milking (n $=87, P=0.60)$, or first milking volume per hour after parturition $(\mathrm{n}=87, P=0.78)$.

Stepwise multivariable linear regression indicated that plasma [Ca] measured in the 24 -h period after parturition was associated with 2 independent factors $\left(\mathrm{n}=84 ; \mathrm{R}^{2}=0.57 ; P<0.0001\right)$ : age $(P<0.0001)$ and milk production on d 28 of lactation $(P=0.0088)$, such that plasma $[\mathrm{Ca}]=2.58-0.092 \times($ age $)-0.0066 \times$ (production). The interaction term between age and milk production on d 28 of lactation was not significant.

\section{DISCUSSION}

The first major finding of this study was that plasma [Ca] was decreased below $2.15 \mathrm{mmol} / \mathrm{L}$ at least $9 \mathrm{~h}$ before parturition and remained decreased for $48 \mathrm{~h}$ after parturition in multiparous Holstein-Friesian cattle fed an acidogenic diet (DCAD: $-18 \mathrm{mEq} / 100 \mathrm{~g}$ of $\mathrm{DM}$ ) in late gestation. The second major finding was that plasma [Ca] in the 12 -h period before and the $24-\mathrm{h}$ period after parturition was strongly and negatively associated with age. Additional major findings were that plasma [Ca] in the 12-h period before parturition was negatively associated with the glandular cistern area (an index of colostral volume), and that plasma [Ca] in the 24-h period after parturition explained 28 to $33 \%$ of the variance in milk production indices, being negatively associated with d-28 milk production, cumulative 

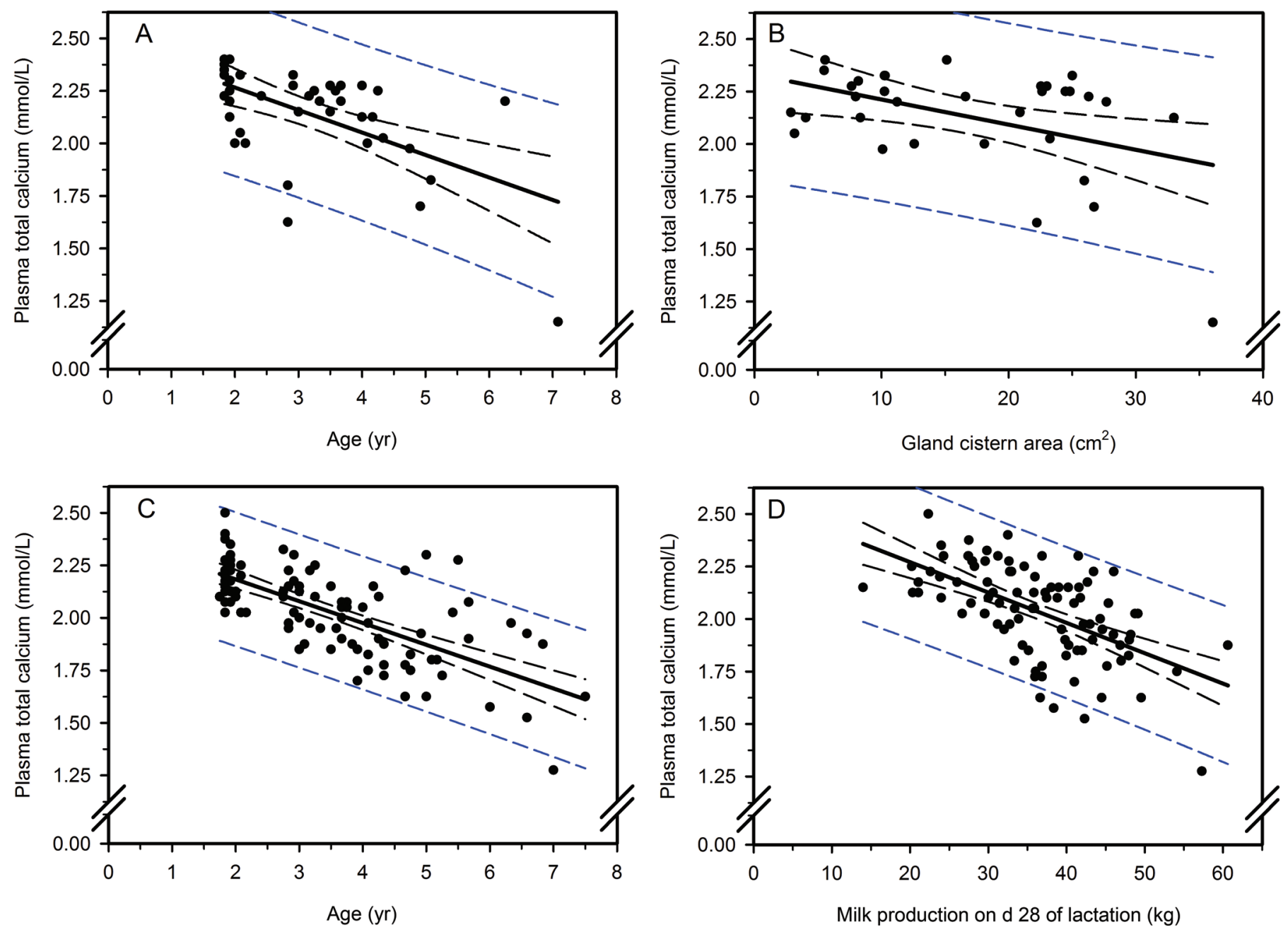

Figure 9. (A) Negative linear relationship between plasma calcium concentration ([Ca]) in the last $12 \mathrm{~h}$ before parturition and age in 40 Holstein-Friesian cattle. The solid line is the regression line $\{$ plasma $[\mathrm{Ca}]=2.48-0.11 \times($ age $)\}$, the medium dashed line is the $95 \% \mathrm{CI}$ for the regression line, and the short dashed line is the $95 \%$ CI for prediction. (B) Negative linear relationship between plasma [Ca] in the last $12 \mathrm{~h}$ before parturition and gland cistern area measured ultrasonographically in 33 Holstein-Friesian cattle; regression equation: plasma [Ca] $=2.33-$ $0.012 \times($ area $) .(C)$ Negative linear relationship between plasma [Ca] in the 24-h period after parturition and age in 97 Holstein-Friesian cattle; regression equation: plasma $[\mathrm{Ca}]=2.39-0.10 \times($ age $)$. (D) Negative linear relationship between plasma [Ca] in the 24-h period after parturition and milk production on d 28 of lactation in 96 Holstein-Friesian cattle; regression equation: plasma $[\mathrm{Ca}]=2.56-0.014 \times($ production). Color version available online.

milk production to $\mathrm{d} 28$, and total milk production. Our findings are consistent with long-held hypotheses that periparturient hypocalcemia results from deranged calcium homeostasis due to the rapid loss of Ca into the mammary gland during colostrogenesis and an age-dependent ability to rapidly mobilize Ca from body stores (Hibbs et al., 1951; Ramburg et al., 1984) and absorb $\mathrm{Ca}$ from the gastrointestinal tract (Martín-Tereso and Verstegen, 2011).

The study reported here appears to be the first involving a large number of dairy cattle $(\mathrm{n}=104)$ that permitted a more complete characterization of the change in plasma $[\mathrm{Ca}$ ] during the 24 - $\mathrm{h}$ period before and after parturition. It should be noted that our re- sults were consistent with those reported in 5 studies involving small numbers of dairy cows that identified a prepartum decrease in plasma [Ca] below $2.15 \mathrm{mmol} / \mathrm{L}$ (Horst et al., 1978; Horst and Jorgensen, 1982; Goff et al., 1989; Sato et al., 2003; Kimura et al., 2006). However, the dairy cows used in those studies were not fed an acidogenic diet in the late dry period and most showed clinical signs of hypocalcemia, and the specific timing of the decrease in plasma $[\mathrm{Ca}]$ relative to parturition was not well characterized.

Most randomized clinical trials have failed to demonstrate a beneficial effect of post-calving oral or subcutaneous Ca supplementation on the incidence and severity of hypocalcemia (Melendez et al., 2002; 
Oetzel and Miller, 2012; Blanc et al., 2014). One of these trials demonstrated that post-calving oral $\mathrm{Ca}$ administration reduced the incidence of health events in cows diagnosed as lame in the first 30 DIM and production benefits in high-production cows (Oetzel and Miller, 2012). A recent trial demonstrated modest health benefits of post-calving oral Ca administration in multiparous cattle (Martinez et al., 2016a) and improved reproductive performance in multiparous cattle and milk yield in multiparous cattle of greater production potential (Martinez et al., 2016b). Our finding that mean plasma $[\mathrm{Ca}]$ was decreased by $9 \mathrm{~h}$ before parturition contrasts with the consensus view that plasma $[\mathrm{Ca}]$ does not decrease until after parturition, and suggests that post-calving $\mathrm{Ca}$ administration may be administered too late to be beneficial. We hypothesize that prepartum calcium treatment may benefit multiparous cows more than postpartum calcium treatment. This hypothesis warrants further research. Support for this hypothesis is provided by the results of studies in dairy cattle demonstrating that prepartum $\mathrm{Ca}$ administration decreased the incidence of parturient paresis and left displaced abomasum (Ringarp et al., 1967; Jonsson and Pehrson, 1970; Oetzel, 1996; Thilsing-Hansen et al., 2002). The accurate prediction of parturition within 6 to $12 \mathrm{~h}$ remains a major challenge in implementing prepartum $\mathrm{Ca}$ administration.

The negative relationship between plasma [Ca] before and after parturition and age observed in this study was consistent with findings in other studies that evaluated risk factors for periparturient hypocalcemia and subclinical hypocalcemia (Dyrendahl et al., 1972; Reinhardt et al., 2011; Miltenburg et al., 2016). Bone growth and loss of calcium to bone slows with advancing age in Holstein-Friesian cattle (Ramberg et al., 1976), with mature skeletal size being reached at 5 yr of age, based on changes in intrapelvic height and depth that has been previously reported in this study population (Hiew et al., 2016). Growing bones have a larger number of, and more active, osteoclasts than mature bones; therefore, primiparous cows can respond to PTH more effectively than multiparous cows (Horst et al., 1990). In addition, multiparous cows have fewer intestinal vitamin D receptors, resulting in decreased intestinal epithelial cell responsiveness to vitamin D (Horst et al., 1997). Consequently, older cattle have a decreased ability to rapidly mobilize skeletal Ca stores and absorb Ca from the gastrointestinal tract (MartínTereso and Verstegen, 2011).

This appears to be the first study in dairy cattle to use ultrasonography to characterize prepartum changes in glandular secretion rates. We identified substantial cow-to-cow variability in gland cistern area, which was consistent with a large variability in colostral volume at the first milking after parturition (Morin et al., 2010; Kessler et al., 2014). The larger mean gland cistern area in multiparous cows was consistent with previous observations that gland cistern area increases with age (Bruckmaier et al., 1994).

The exact time for transition from colostrogenesis to lactogenesis (manifested as "bagging up," an observable sudden increase in mammary gland volume) varies from cow to cow (Baumrucker and Bruckmaier, 2014). This variability is likely to affect the variability in plasma $[\mathrm{Ca}]$ in the periparturient period because colostrum contains approximately 3 times more casein than milk, permitting colostral secretions to attain a higher [Ca] than that of milk (Tsioulpas et al., 2007). The high [Ca] in colostrum, in conjunction with our ultrasonographic findings of increased glandular secretion rates in the last $24 \mathrm{~h}$ before parturition, supports the widely held view of a marked increase in calcium loss to the mammary gland in the 24 -h period immediately before parturition. The rate of calcium loss in some animals exceeds the ability of homeostatic mechanisms to maintain plasma $[\mathrm{Ca}]$, resulting in a decrease in plasma $[\mathrm{Ca}]$ at least $9 \mathrm{~h}$ before parturition. Late-gestation dairy cattle mobilize $\mathrm{Ca}$ at $0.50 \mathrm{~g} / \mathrm{h}$, which is considerably lower than the Ca mobilization rate of $0.87 \mathrm{~g} / \mathrm{h}$ for nonpregnant dry cows (Payne, 1964). Moreover, the Ca mobilization rate of third- or greater-parity cows at $10 \mathrm{~h}$ postpartum was 9 to $26 \%$ lower than the mobilization rate in first- or second-parity cattle (van de Braak et al., 1986). In other words, although Ca loss via colostrogenesis precipitates periparturient hypocalcemia by acting as the primary disturbing factor (Ramberg et al., 1970, 1984), short-term $\mathrm{Ca}$ homeostasis in the periparturient period is predominantly due to an age-dependent ability to mobilize calcium from tissue reserves, primarily bone (Hibbs et al., 1951) and an age-dependent ability to increase the rate of $\mathrm{Ca}$ absorption from the gastrointestinal tract (Martín-Tereso and Verstegen, 2011). Bone Ca resorption is initiated by PTH release, and pregnant dairy cows require approximately $48 \mathrm{~h}$ of PTH stimulation to effectively mobilize bone Ca (Goff et al., 1986; Martín-Tereso and Verstegen, 2011). This timeline was consistent with our finding that plasma [Ca] was decreased for 2 to $3 \mathrm{~d}$ in the periparturient period.

We found that plasma [Ca] was not associated with first milking volume (actual volume or indexed on the number of hours since parturition), possibly because the time from parturition to first milking and colostral milking process was not standardized. We speculate that cow-to-cow variability in oxytocin release at first milking may also have affected this finding. Nevertheless, we did identify a negative association between plasma [Ca] in the $12 \mathrm{~h}$ before parturition and gland cistern area, as well as a negative association between plasma [Ca] 
in the first $24 \mathrm{~h}$ after parturition and milk production on d 28 of lactation and cumulative milk production for the first 28 DIM. These associations support long-held modeling assumptions that the amount of glandular tissue, and therefore the Ca mass lost in colostrogenesis, is the primary disturbing signal in periparturient $\mathrm{Ca}$ homeostasis (Ramburg et al., 1970, 1984).

Feeding an acidogenic diet induces aciduria due to excessive proton excretion in urine. The changes in urine $\mathrm{pH}$ in the periparturient period in the study reported here are consistent with results from other studies that urine $\mathrm{pH}$ of dairy cows fed acidogenic diets in the late dry period does not increase until 12 to $24 \mathrm{~h}$ postpartum (DeGaris and Lean, 2008; Grünberg et al., 2011). The amount of Ca excreted in urine over $24 \mathrm{~h}$ is increased 6 -fold in animals fed an acidogenic diet $(-9 \mathrm{mEq} / 100$ $\mathrm{g}$ of DM) before calving compared with animals fed a DCAD diet of $+11 \mathrm{mEq} / 100 \mathrm{~g}$ of DM (Grünberg et al., 2011). In other words, feeding an acidogenic diet in late gestation promotes aciduria and hypercalciuria. A low luminal $\mathrm{pH}$ in the second half of the distal convoluted tubule and connecting tubule decreases the number and activity of epithelial Ca channels called TRPV5 (transient receptor potential vanilloid member 5). This directly results in hypercalciuria because TRPV5 channels are the primary gatekeepers of active calcium resorption in the distal region of the mammalian urinary tract (Constable et al., 2010; Martín-Tereso and Verstegen, 2011; Bonny and Edwards, 2013).

We found that the decrease in plasma [Ca] in multiparous cows at least $9 \mathrm{~h}$ before calving was associated with a decrease in the calculated 24-h urinary Ca excretion in multiparous cattle of 3.5 to $3.8 \mathrm{~g}$ of $\mathrm{Ca}$ in the periparturient period to meet the excessive loss of $\mathrm{Ca}$ into the mammary gland associated with colostrogenesis. The reabsorption of $\mathrm{Ca}$ from the urine increased the amount of $\mathrm{Ca}$ available in the exchangeable $\mathrm{Ca}$ pool and most likely facilitated calcium homeostasis. This is best appreciated by comparing the calculated reabsorbed Ca mass of 3.5 to $3.8 \mathrm{~g}$ to the 6 to $12 \mathrm{~g}$ of $\mathrm{Ca}$ that is routinely administered intravenously to dairy cows to treat periparturient hypocalcemia (Alanko et al., 1975; Doze at al., 2008). Reabsorption of 3.5 to 3.8 $\mathrm{g}$ of Ca from urine over $24 \mathrm{~h}$ will increase plasma [Ca] by approximately $0.5 \mathrm{mmol} / \mathrm{L}(2.0-2.2 \mathrm{mg} / \mathrm{dL})$, assuming an extracellular distribution volume of $26 \%$ of BW for a 675-kg cow (Grünberg et al., 2011). Periparturient urine reabsorption of $\mathrm{Ca}$ in cows fed a low-DCAD diet is therefore likely to be responsible for at least part of the decreased incidence of clinical and subclinical hypocalcemia in cattle fed acidogenic diets in late gestation (Grünberg et al., 2011).

Decreased DMI is considered a potential contributor to periparturient hypocalcemia, although univariable and multivariable linear regression analysis did not identify an association between feed intake and plasma [Ca] in the $12 \mathrm{~h}$ before or the $24 \mathrm{~h}$ after parturition. Feed intake is physiologically decreased during the last few weeks of gestation and is decreased to a greater extent in multiparous cows than in primiparous cows, reaching a nadir on the day of parturition (Ingvartsen and Andersen, 2000). Of interest in the study reported here is the marked cow-to-cow variability in DMI; such variability is not easily discerned when experimental data are presented as least squares means and standard errors. However, despite the variability in DMI and consequently $\mathrm{Ca}$ intake, feed intake was not an important predictor of plasma $[\mathrm{Ca}]$ in the periparturient period.

Episodes of hypocalcemia at calving in multiparous cows are always associated with hypophosphatemia (Hove, 1986). The decrease in plasma [Pi] around calving is most likely due to excessive loss of $\mathrm{Pi}$ to the mammary gland during colostrogenesis and lactogenesis, as milk contains 0.7 to $1.3 \mathrm{~g}$ of $\mathrm{Pi} / \mathrm{L}$, and release of $\mathrm{PTH}$ in response to hypocalcemia with subsequent increased renal and salivary loss of Pi (Goff et al., 1989). Other potential contributing mechanisms to postparturient hypophosphatemia include ingesting an acidogenic diet prepartum as metabolic acidosis and aciduria increases renal Pi loss (Grünberg et al., 2011), the increase in plasma [cortisol] around calving stimulates Pi influx from the extracellular to intracellular space (Horst and Jorgensen, 1982) and decreases the renal reabsorptive capacity of Pi (Kim et al., 2012). In addition, the increase in plasma insulin concentration around calving in response to hypercortisolemia-induced hyperglycemia stimulates Pi influx from the extracellular to the intracellular space, particularly into skeletal muscle cells (Grünberg et al., 2006).

The periparturient increase in plasma $[\mathrm{Mg}]$ observed in this study is consistent with findings of previous studies (Hove, 1986; Goff et al., 2002). The periparturient increase in plasma $[\mathrm{Mg}]$ is most frequently attributed to increased renal $\mathrm{Mg}$ reabsorption in response to a reduction in plasma $[\mathrm{Ca}]$ that stimulates PTH release (Goff et al., 1986).

The major limitation with this study was that it was conducted on one farm; additional studies are therefore indicated to determine the external validity of the results. More intensive sampling, such as every $12 \mathrm{~h}$ in the periparturient period or at standardized time intervals after parturition, than the 24-h sampling interval used herein will provide higher resolution information of the time course of periparturient changes in plasma [Ca]. Other limitations were that farm-to-farm variations in the percentage $\mathrm{Ca}$ fed on a DM basis from those in the study reported here $(1.03 \%$ in close-up ration and $0.90 \%$ in lactation ration) and farm-to-farm variations 
in the DCAD of the close-up ration and lactation ration may influence the time of onset of periparturient hypocalcemia relative to parturition, as well as the magnitude and duration of subclinical hypocalcemia. Finally, the incidence of periparturient hypocalcemia diagnosed in this study using clinical signs alone was $8.6 \%$ in multiparous cattle. Whether the calculated mean Ca intake of $101 \mathrm{~g}$ in the 24-h period before parturition in multiparous cattle contributed to the higher than anticipated incidence of periparturient hypocalcemia remains an area of interest (Lean et al., 2006; Schröder and Breves, 2006; DeGaris and Lean, 2008).

\section{CONCLUSIONS}

Plasma [Ca] was decreased at least $9 \mathrm{~h}$ before parturition and calcium homeostasis was disrupted for 2 to $3 \mathrm{~d}$ around parturition in multiparous dairy cattle fed an acidogenic diet in late gestation. Plasma $[\mathrm{Ca}]$ in the 24-h period after parturition was negatively associated with age and indices of increased milk production.

\section{ACKNOWLEDGMENTS}

The authors thank the staff of the Purdue University Dairy Research and Education Center (West Lafayette, IN) for their tireless help and support. Funding for this study was provided, in part, by a Government Mission Program grant from the Cultural and Educational Bureau, Embassy of the Arab Republic of Egypt (S. El Badawy, A. A. Megahed), and the Scholarship Division, Ministry of Education, Malaysia (M. W. H. Hiew).

\section{REFERENCES}

Abd El-Fattah, A. M., F. H. R. Abd Rabo, S. M. El-Dieb, and H. A. El-Kashef. 2012. Changes in composition of colostrum of Egyptian buffaloes and Holstein cows. BMC Vet. Res. 8:19.

Alanko, M., B. Cederquist, K. Jonsgard, G. Jönsson, P. Nurmio, B. Pehrson, and M. G. Simesen. 1975. The effect of different calcium doses in milk fever therapy: A comparative internordic field study. Nord. Vet. Med. 27:616-626.

Ayadi, M., G. Caja, X. Such, and C. H. Knight. 2003. Use of ultrasonography to estimate cistern size and milk storage at different milking intervals in the udder of dairy cows. J. Dairy Res. 70:1-7.

Baumrucker, C. R., and R. M. Bruckmaier. 2014. Colostrogenesis: $\mathrm{IgG}_{1}$ transcytosis mechanisms. J. Mammary Gland Biol. Neoplasia 19:103-117.

Blanc, C. D., M. van der List, S. S. Aly, H. A. Rossow, and N. Silvadel-Río. 2014. Blood calcium dynamics after prophylactic treatment of subclinical hypocalcemia with oral or intravenous calcium. J. Dairy Sci. 97:6901-6906.

Bojkovski, J., S. Borozan, I. Jozef, and H. Samanc. 2005. Colostrum composition before and after calving in Holstein-Friesian cows. Vet. Rec. 156:744-745.

Bonny, O., and A. Edwards. 2013. Calcium reabsorption in the distal tubule: Regulation by sodium, pH, and flow. Am. J. Physiol. Renal Physiol. 304:F585-F600.
Bruckmaier, R. M., E. Rothenanger, and J. W. Blum. 1994. Measurement of mammary gland cistern size and determination of the cisternal milk fraction in dairy cows. Milchwissenschaft 49:543-546.

Caja, G., M. Ayadi, and C. H. Knight. 2004. Changes in cisternal compartment based on stage of lactation and time since milk ejection in the udder of dairy cows. J. Dairy Sci. 87:2409-2415.

Charbonneau, E., D. Pellerin, and G. R. Oetzel. 2006. Impact of lowering dietary cation-anion difference in nonlactating dairy cows: A meta-analysis. J. Dairy Sci. 89:537-548.

Constable, P. D., W. Grünberg, H. Staempfli, and R. Staufenbiel. 2010. Monitoring DCAD diets in dairy cattle. Abstract 1904 in Proc. XXVI World Buiatrics Congress 2010, Santiago, Chile. www .wbc-2010.com.

DeGaris, P. J., and I. J. Lean. 2008. Milk fever in dairy cows: A review of pathophysiology and control principles. Vet. J. 176:58-69.

Doze, J. G., R. Donders, and J. H. van der Kolk. 2008. Effects of intravenous administration of two volumes of calcium solution on plasma ionized calcium concentration and recovery from naturally occurring hypocalcemia in lactating dairy cows. Am. J. Vet. Res. 69:1346-1350.

Dyrendahl, I., B. Henricson, and G. Jönsson. 1972. Clinical puerperal paresis and hypocalcaemia in cattle. A statistical and genetic investigation. Zentralbl. Veterinarmed. A 19:621-638.

Goff, J. P., K. Kimura, and R. Horst. 2002. Effect of mastectomy on milk fever, energy, and vitamins $\mathrm{A}, \mathrm{E}$, and $\beta$-carotene status at parturition. J. Dairy Sci. 85:1427-1436.

Goff, J. P., E. T. Littledike, and R. L. Horst. 1986. Effect of synthetic bovine parathyroid hormone in dairy cows: prevention of hypocalcemic parturient paresis. J. Dairy Sci. 69:2278-2289.

Goff, J. P., T. A. Reinhardt, and R. L. Horst. 1989. Recurring hypocalcemia of bovine parturient paresis is associated with failure to produce 1,25-dihydroxyvitamin D. Endocrinology 125:49-53.

Grünberg, W., S. S. Donkin, and P. D. Constable. 2011. Periparturient effects of feeding a low dietary cation-anion difference diet on acidbase, calcium, and phosphorus homeostasis and on intravenous glucose tolerance test in high-producing dairy cows. J. Dairy Sci. 94:727-745.

Grünberg, W., D. E. Morin, J. K. Drackley, and P. D. Constable. 2006. Effect of rapid intravenous administration of $50 \%$ dextrose solution on phosphorus homeostasis in postparturient dairy cows. J. Vet. Intern. Med. 20:1471-1478.

Heinrichs, A. J., G. Rogers, and J. Cooper. 1992. Predicting body weight and wither height in Holstein heifers using body measurements. J. Dairy Sci. 75:3576-3581.

Hibbs, J. W.. W. D. Pounden, and W. E. Krauss. 1951. Studies on milk fever in dairy cows. III. Further studies on the effect of vitamin D on some of the blood changes at parturition and the composition of colostrum in normal and milk-fever cows. J. Dairy Sci. 34:855-864

Hiew, M. W., A. A. Megahed, J. R. Townsend, W. L. Singleton, and P. D. Constable. 2016. Clinical utility of calf front hoof circumference and maternal intrapelvic area in predicting dystocia in 103 late gestation Holstein-Friesian heifers and cows. Theriogenology 85:384-395.

Horst, R. L., H. F. DeLuca, and N. A. Jorgensen. 1978. The effect of age on calcium absorption and accumulation of 1,25-dihydroxyvitamin D3 in intestinal mucosa of rats. Metab. Bone Dis. Relat. Res. 1:29-33.

Horst, R. L., J. P. Goff, and B. McCluskey. 2003. Prevalence of subclinical hypocalcemia in U.S. dairy operations. USDA Agricultural Research Service, Washington, DC.

Horst, R. L., J. P. Goff, and T. A. Reinhardt. 1990. Advancing age results in reduction of intestinal and bone 1,25-dihydroxyvitamin D receptor. Endocrinology 126:1053-1057.

Horst, R. L., J. P. Goff, and T. A. Reinhardt. 1994. Calcium and vitamin D metabolism in the dairy cow. J. Dairy Sci. 77:1936-1951.

Horst, R. L., P. J. Goff, A. T. Reinhardt, and R. D. Buxton. 1997. Strategies for preventing milk fever in dairy cattle. J. Dairy Sci. $80: 1269-1280$. 
Horst, R. L., and N. A. Jorgensen. 1982. Elevated plasma cortisol during induced and spontaneous hypocalcemia in ruminants. J. Dairy Sci. 65:2332-2337.

Hove, K. 1986. Cyclic changes in plasma calcium and the calcium homeostatic endocrine system of the postparturient dairy cow. J. Dairy Sci. 69:2072-2082.

Ingvartsen, K. L., and J. B. Andersen. 2000. Integration of metabolism and intake regulation: A review focusing on periparturient animals. J. Dairy Sci. 83:1573-1597.

Jonsson, G., and B. Pehrson. 1970. Trials with prophylactic treatment of parturient paresis. Vet. Rec. 87:575-578.

Kessler, E. C., J. J. Gross, R. M. Bruckmaier, and C. Albrecht. 2014. Cholesterol metabolism, transport, and hepatic regulation in dairy cows during transition and early lactation. J. Dairy Sci. 97:54815490.

Kim, D., N. Yamagishi, B. Devkota, and K. Furuhama. 2012. Effects of cortisol secreted via a 12-h infusion of adrenocorticotropic hormone on mineral homeostasis and bone metabolism in ovariectomized cows. Domest. Anim. Endocrinol. 43:264-269.

Kimura, K., T. A. Reinhardt, and J. P. Goff. 2006. Parturition and hypocalcaemia blunts calcium signals and immune cells of dairy cattle. J. Dairy Sci. 89:2588-2595.

Kume, S., T. Toharmat, and N. Kobayashi. 1998. Effect of restricted feed intake of dams and heart stress on mineral status of newborn calves. J. Dairy Sci. 81:1581-1590.

Lean, I. J., P. J. DeGaris, D. M. McNeil, and E. Block. 2006. Hypocalcemia in dairy cows: Meta-analysis and dietary cation anion difference theory revisited. J. Dairy Sci. 89:669-684.

Littell, R. C., P. R. Henry, and C. B. Ammerman. 1998. Statistical analysis of repeated measures data using SAS procedures. J. Anim. Sci. 76:1216-1231.

Liu, C., D. Cao, P. Chen, and T. Zagar. 2007. RANDOM and REPEATED statements: How to use them to model the covariance structure in Proc Mixed. Paper S02-2007 in SAS Conference Proceedings: Midwest SAS User Group. Accessed Nov. 15, 2017. http://mwsug.org/proceedings/2007/stats/MWSUG-2007-S02 .pdf.

Martín-Tereso, J., and M. W. Verstegen. 2011. A novel model to explain dietary factors affecting hypocalcaemia in dairy cattle. Nutr. Res. Rev. 24:228-243.

Martinez, N., C. A. Risco, F. S. Lima, R. S. Bisinptto, L. F. Greco, E. S. Ribeiro, F. Maunsell, K. Galvao, and J. E. Santos. 2012. Evaluation of peripartal calcium status, energetic profile, and neutrophil function in dairy cows at low or high risk of developing uterine disease. J. Dairy Sci. 95:7158-7172.

Martinez, N., L. D. P. Sinedino, R. S. Bisinotto, R. Daetz, C. Lopera, C. A. Risco, K. N. Galvão, W. W. Thatcher, and J. E. P. Santos. 2016a. Effects of oral calcium supplementation on mineral and acid-base status, energy metabolites, and health of postpartum dairy cows. J. Dairy Sci. 99:8397-8416.

Martinez, N., L. D. P. Sinedino, R. S. Bisinotto, R. Daetz, C. A. Risco, K. N. Galvão, W. W. Thatcher, and J. E. P. Santos. 2016b. Effects of oral calcium supplementation on productive and reproductive performance in Holstein cows. J. Dairy Sci. 99:8417-8430.

Megahed, A. A., M. Hiew, and P. D. Constable. 2017a. Ultrasonographic determination of longissimus dorsi muscle thickness and intramuscular fat percentage in periparturient dairy cattle. J. Vet. Intern. Med. 31:1360.

Megahed, A. A., M. W. Hiew, J. R. Townsend, and P. D. Constable. 2017b. Characterization of the analytic performance of an electrochemical point-of-care meter for measuring $\beta$-hydroxybutyrate concentration in blood and plasma from periparturient dairy cattle. Vet. Clin. Pathol. 46:314-325.

Megahed, A. A., M. W. Hiew, J. R. Townsend, J. B. Messick, and P. D. Constable. 2015. Evaluation of an electrochemical point-of-care meter for measuring glucose concentration in blood from periparturient dairy cattle. J. Vet. Intern. Med. 29:1718-1727.

Melendez, P., A. Donovan, C. A. Risco, M. B. Hall, R. Littell, and J. P. Goff. 2002. Metabolic responses of transition Holstein cows fed anionic salts and supplemented at calving with calcium and energy. J. Dairy Sci. 85:1085-1092.

Miltenburg, C. L., T. F. Duffield, D. Bienzle, E. L. Scholtz, and S. J. LeBlanc. 2016. Randomized clinical trial of a calcium supplement for improvement of health in dairy cows in early lactation. J. Dairy Sci. 99:6550-6562.

Morin, D. E., S. V. Nelson, E. D. Reid, D. W. Nagy, G. E. Dahl, and P. D. Constable. 2010. Effect of colostral volume, interval between calving and first milking, and photoperiod on colostral IgG concentrations in dairy cows. J. Am. Vet. Med. Assoc. 237:420-428.

NRC. 2001. Nutrient Requirements of Dairy Cattle. 7th rev. ed. National Academies Press, Washington, DC.

Oetzel, G. R. 1996. Calcium chloride gel treatment of parturient dairy cows: Effect on hypocalcemia and parturient diseases. J. Am. Vet. Med. Assoc. 209:958-961.

Oetzel, G. R., and B. E. Miller. 2012. Effect of oral calcium bolus supplementation on early-lactation health and milk yield in commercial dairy herds. J. Dairy Sci. 95:7051-7065.

Payne, J. M. 1964. The response of cows to experimentally induced hypocalcemia. II. Chronic experimental hypocalcemia. Vet. Rec. 76:77-81.

Ramberg, C. F., Jr., E. K. Johnson, R. D. Fargo, and D. S. Kronfeld. 1984. Calcium homeostasis in cows, with special reference to parturient hypocalcemia. Am. J. Physiol. 246:R698-704.

Ramberg, C. F., Jr., G. P. Mayer, D. S. Kronfeld, J. M. Phang, and M. Berman. 1970. Calcium kinetics in cows during late pregnancy, parturition, and early lactation. Am. J. Physiol. 219:1166-1177.

Ramberg, C. F., Jr., G. P. Mayer, D. S. Kronfeld, and J. T. Potts. 1976. Dietary calcium, calcium kinetics and plasma parathyroid hormone concentration in cows. J. Nutr. 106:671-679.

Reinhardt, T. A., J. D. Lippolis, B. J. McCluskey, J. P. Goff, and R. L. Horst. 2011. Prevalence of subclinical hypocalcemia in dairy herds. Vet. J. 188:122-124.

Ringarp, N., C. Rydberg, O. Damberg, and B. Bostrom. 1967. Study of a prophylactic therapy of puerperal paresis in cows by means of oral administration of calcium chloride gel. Zentralbl. Veterinarmed. A 14:242-251.

Roche, J. R., D. Dalley, P. Moate, C. Grainger, M. Rath, and F. O'Mara. 2003a. Dietary cation-anion difference and the health and production of pasture-fed dairy cows 2. Nonlactating periparturient cows. J. Dairy Sci. 86:979-987.

Roche, J. R., D. Dalley, P. Moate, C. Grainger, M. Rath, and F. O'Mara. 2003b. Dietary cation-anion difference and the health and production of pasture-fed dairy cows. 1. Dairy cows in early lactation. J. Dairy Sci. 86:970-978.

Sato, J., R. Sato, A. Takagi, T. Goto, K. Okada, J. Yasuda, and Y. Naito. 2003. Association between changes in plasma calcium concentration and plasma tartrate-resistant acid phosphatase activity in periparturient cows. J. Vet. Med. Sci. 65:291-293.

Schröder, B., and G. Breves. 2006. Mechanisms and regulation of calcium absorption from the gastrointestinal tract in pigs and ruminants: comparative aspects with special emphasis on hypocalcemia in dairy cows. Anim. Health Res. Rev. 7:31-41.

Thilsing-Hansen, T., R. J. Jørgensen, and S. Østergaard. 2002. Milk fever control principles: A review. Acta Vet. Scand. 43:1-19.

Tsioulpas, A., A. S. Grandison, and M. J. Lewis. 2007. Changes in physical properties of bovine milk from the colostrum period to early lactation. J. Dairy Sci. 90:5012-5017.

Valadares, R. F. D., G. A. Broderick, S. C. Valadares Filho, and M. K. Clayton. 1999. Effect of replacing alfalfa silage with high moisture corn on ruminal protein synthesis estimated from excretion of total purine derivatives. J. Dairy Sci. 82:2686-2696.

van de Braak, A. E., A. T. van 't Klooster, and A. Malestein. 1986. Influence of prepartum calcium intake on calcium mobilization rate around parturition in dairy cows fed at a high prepartum feeding level. Vet. Q. 8:24-37. 